\title{
Steroids and Sesquiterpenoids from the Soft Corals Dendronephthya gigantea and Lemnalia cervicorni
}

\author{
Chang-Yih Duh, ${ }^{, \dagger}{ }^{\dagger}$ Ali A. H. El-Gamal, ${ }^{\dagger, \neq}$ Pei-Ying Song, ${ }^{\dagger}$ Shang-K wei Wang, ${ }^{\S}$ and Chang-Feng Dai ${ }^{\perp}$ \\ Department of Marine Resources, National Sun Yat-sen University, Kaohsiung, Taiwan, Department of Microbiology, \\ Kaohsiung Medical University, Kaohsiung, Taiwan, and Institute of Oceanography, National Taiwan University, \\ Taipei, Taiwan, Republic of China
}

Recei ved December 31, 2003

One new cytotoxic steroid, dendronesterone A (1), two new steroids, dendronesterones B and C (2 and 3), and a known steroid (4) were isolated from the methylene chloride solubles of the Formosan soft coral Dendronephthya gigantea. Two cytotoxic ylangene-type sesquiterpenoids, lemnalol (5) and the new compound cervicol (6), as well as two ylangene-type sesquiterpenoids, isolemnalol (7) (a new compound) and 4-oxo- $\alpha$-ylangene (8), were isolated from the methylene chloride solubles of the Formosan soft coral Lemnalia cervicorni. Their structures were elucidated by 1D and 2D NMR spectral analysis, and their cytotoxicity against selected cancer cells was measured in vitro.

The genera Lemnalia and Dendronephthya have afforded bioactive sesquiterpenes ${ }^{1-3}$ and steroids. ${ }^{4-6}$ As part of our search for bioactive substances from marine organisms, the Formosan soft corals Lemnalia cervicorni May (Nephtheidae) and Dendronephthya gigantea Verrill (Nephtheidae) were studied because the $\mathrm{CH}_{2} \mathrm{Cl}_{2}$ extracts showed significant cytotoxicity to $\mathrm{A} 549$ (human lung adenocarcinoma), HT-29 (human colon adenocarcinoma), and P-388 (mouse Iymphocytic leukemia) cell cultures as determined by standard procedures. ${ }^{7,8}$ Bioassay-guided fractionation of $\mathrm{CH}_{2} \mathrm{Cl}_{2}$ extracts of $\mathrm{D}$. gigantea resulted in the isolation of one new cytotoxic steroid, dendronesterone $A(\mathbf{1})$, two new steroids, dendronesterones $\mathrm{B}$ and $\mathrm{C}$ (2 and $\mathbf{3}$ ), and a known steroid (4). Bioassay-guided fractionation of $\mathrm{CH}_{2} \mathrm{Cl}_{2}$ extracts of $\mathrm{L}$. cervicorni resulted in the isolation of two cytotoxic ylangene-type sesquiterpenoids, lemnal ol (5) and a new compound, cervicol (6), as well as two ylangene-type sesquiterpenoids, isolemnalol (7) (a new compound) and 4-oxo- $\alpha$-ylangene (8).

\section{Results and Discussion}

Compound $\mathbf{1}$ had a molecular formula of $\mathrm{C}_{27} \mathrm{H}_{42} \mathrm{O}$ as established by HREIMS. The ${ }^{1} \mathrm{H}$ NMR spectrum revealed the presence of two tertiary methyls $\left(\delta_{\mathrm{H}} 0.71\right.$ and 1.01), three secondary methyls $\left(\delta_{\mathrm{H}} 0.86,0.87\right.$, and 1.01$)$, and two olefinic protons $\left(\delta_{H} 5.20\right.$ and 5.27). The presence of an $\alpha, \beta$ unsaturated carbonyl group was straightforward from NMR signals (Tables 1 and 2) at $\delta_{\mathrm{H}} 5.85 / \delta_{\mathrm{C}} 127.4,7.15 /$ 158.7, and 200.4 (qC), as well as from an IR absorption at $1680 \mathrm{~cm}^{-1}$. The 1D NMR data could account for 3 of the 7 degrees of unsaturation, suggesting the tetracyclic nature of $\mathbf{1}$. Twenty-seven carbons including five methyls suggested that 1 was an analogue of cholesterol. COSY correlation between $\mathrm{H}-22 / \mathrm{H}-23$ and $\mathrm{HMBC}$ correlations between $\mathrm{Me}-21 / \mathrm{C}-17, \mathrm{C}-20, \mathrm{C}-22$, as well as the 22.23 of 15.3 $\mathrm{Hz}$, inferred an $\mathrm{E}$ double bond between $\mathrm{C}-22$ and $\mathrm{C}-23$. Rings $A$ and $B$ were elucidated on the basis of $\mathrm{HMBC}$ crosspeaks between Me-19/C-1, C-5, C-9, C-10 and H-4/C-3, whereas rings $\mathrm{C}$ and $\mathrm{D}$ were completed on the basis of

* To whom correspondence should be addressed. Tel: 886-7-525-2000 ext. 5036. Fax: 886-7-525-5020. E-mail: yihduh@mail.nsysu.edu.tw.

N National Sun Yat-sen University.

₹ On leave from Faculty of Pharmacy, Mansoura University, Egypt.

$\S$ Kaohsiung Medical University.

${ }^{\perp}$ National Taiwan University.
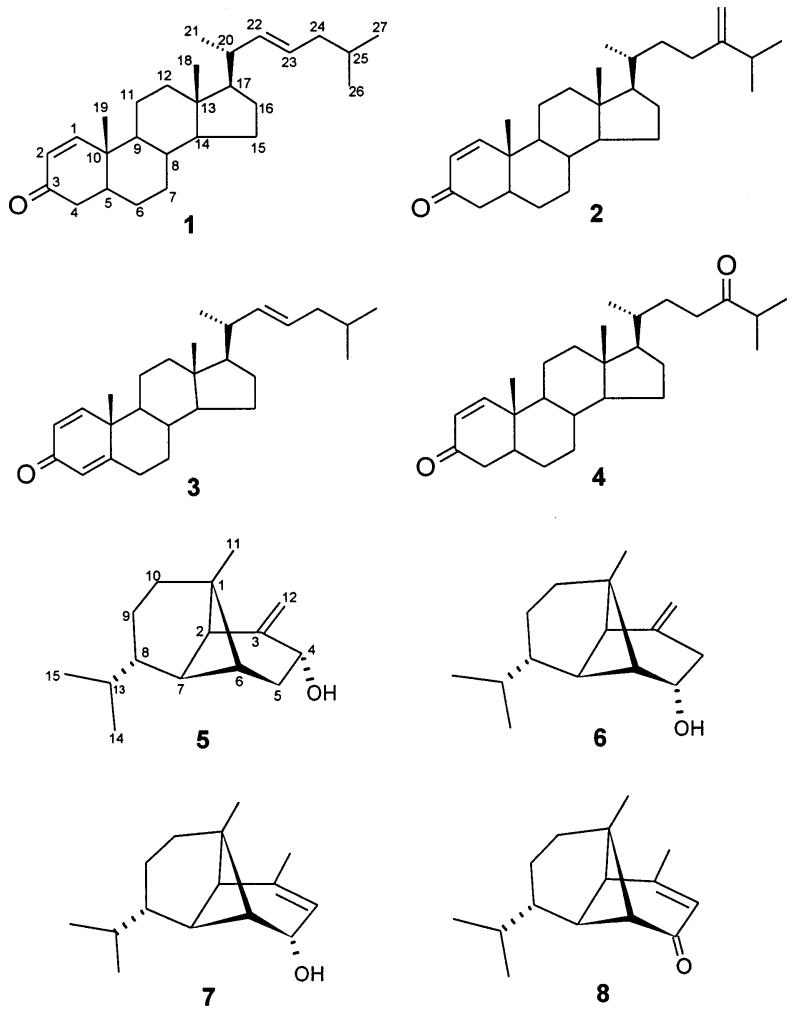

HMBC correlations between Me-18/C-12, C-13, C-14, C-17. Comparison of ${ }^{13} \mathrm{C}$ NMR chemical shift values of 1 with those of five cholesta-1-en-3-ones reported from the octocoral Alcyonium gracillimum ${ }^{9}$ inferred normal stereochemistry of the ring junctures of $\mathbf{1}$. The NOESY correlations observed between $\mathrm{H}-11 \beta$ and $\mathrm{H}-8, \mathrm{H}-11 \beta$ and $\mathrm{H}_{3}-18, \mathrm{H}-11 \beta$ and $\mathrm{H}_{3}-19, \mathrm{H}-9$ and $\mathrm{H}-14, \mathrm{H}_{3}-18$ and $\mathrm{H}-8, \mathrm{H}_{3}-19$ and $\mathrm{H}-8$, $\mathrm{H}_{3}-18$ and $\mathrm{H}-20$, and $\mathrm{H}-9$ and $\mathrm{H}-12 \alpha$ in $\mathbf{1}$ confirmed the relative configurations for each ring junction and chiral center. The stereochemistry of C-20 was determined by comparison of ${ }^{1} \mathrm{H}$ and ${ }^{13} \mathrm{C}$ NMR data with those of $5 \alpha, 8 \alpha-$ epidioxycholesta-6,22-dien-3 $\beta$-ol ${ }^{10}$ and confirmed by NOESY correlation between $\mathrm{H}_{3}-21$ and $\mathrm{H}-12 \beta$.

Compound 2 had a molecular formula of $\mathrm{C}_{28} \mathrm{H}_{44} \mathrm{O}$ as determined by HREIMS. The ${ }^{1} \mathrm{H}$ and ${ }^{13} \mathrm{C}$ NMR spectral data (Tables 1 and 2) resembled those of 1 except for NMR 
Table 1. ${ }^{1} \mathrm{H}$ NMR Data for Metabolites 1-4 in $\mathrm{CDCl}_{3}$

\begin{tabular}{|c|c|c|c|c|}
\hline $\mathrm{H}$ & $\mathbf{1}^{\mathrm{b}}$ & $2^{a}$ & $3^{b}$ & $4^{a}$ \\
\hline 1 & $7.15 d(9.9)$ & $7.15 d(10.0)$ & $7.06 \mathrm{~d}(10.2)$ & $7.14 \mathrm{~d}(10.0)$ \\
\hline $\begin{array}{l}2 \\
3\end{array}$ & $5.85 \mathrm{~d}(9.9)$ & $5.85 \mathrm{~d}(10.0)$ & $6.23 \mathrm{dd}(10.2,1.8)$ & $5.86 \mathrm{dd}(10.0,0.5)$ \\
\hline $4 \alpha$ & $2.21 \mathrm{dd}(18.0,4.5)$ & $2.23 \mathrm{dd}(17.5,6.5)$ & $6.07 \mathrm{~s}$ & 2.22 ddd $(17.5,3.5,0.5)$ \\
\hline $4 \beta$ & $2.37 \mathrm{dd}(18.0,14.0)$ & $2.37 \mathrm{dd}(17.5,14.8)$ & & $2.37 \mathrm{dd}(17.5,14.0)$ \\
\hline 5 & $1.96 \mathrm{~m}$ & $1.90 \mathrm{~m}$ & & $1.92 \mathrm{~m}$ \\
\hline $6 \alpha$ & $1.29 \mathrm{~m}$ & $1.84 \mathrm{~m}$ & $2.37 \mathrm{tt}(12.9,2.4)$ & $1.42 \mathrm{~m}$ \\
\hline $6 \beta$ & $1.72 \mathrm{~m}$ & & $2.46 \operatorname{tdd}(12.9,3.9,1.5)$ & \\
\hline 7 & $1.76 \mathrm{~m}$ & $1.71 \mathrm{~m}$ & $1.14 \mathrm{~m}$ & $0.95 \mathrm{~m}, 1.72 \mathrm{~m}$ \\
\hline 8 & $1.50 \mathrm{~m}$ & $1.42 \mathrm{~m}$ & $1.28 \mathrm{~m}$ & $1.43 \mathrm{~m}$ \\
\hline 9 & $1.01 \mathrm{~m}$ & $0.98 \mathrm{~m}$ & $1.14 \mathrm{~m}$ & $1.22 \mathrm{~m}$ \\
\hline $11 \alpha$ & $1.79 \mathrm{~m}$ & $1.71 \mathrm{~m}$ & $1.12 \mathrm{~m}$ & $1.75 \mathrm{~m}$ \\
\hline $11 \beta$ & $1.52 \mathrm{~m}$ & $2.28 \mathrm{~m}$ & $1.74 \mathrm{~m}$ & $1.45 \mathrm{~m}$ \\
\hline $12 \alpha$ & $1.18 \mathrm{~m}$ & $1.17 \mathrm{~m}$ & $1.18 \mathrm{~m}$ & $1.31 \mathrm{~m}$ \\
\hline $12 \beta$ & $2.05 \mathrm{~m}$ & $2.04 \mathrm{~m}$ & $2.05 \mathrm{~m}$ & $1.99 \mathrm{dt}(12.5,3.0)$ \\
\hline 14 & $1.18 \mathrm{~m}$ & $1.07 \mathrm{~m}$ & $1.01 \mathrm{~m}$ & $1.10 \mathrm{~m}$ \\
\hline 15 & $1.60 \mathrm{~m}$ & $1.08 \mathrm{~m}, 1.58 \mathrm{~m}$ & $1.61 \mathrm{~m}$ & $1.12 \mathrm{~m}, 1.59 \mathrm{~m}$ \\
\hline 16 & $1.46 \mathrm{~m}$ & $1.40 \mathrm{~m}$ & $1.72 \mathrm{~m}$ & $1.12 \mathrm{~m}, 1.65 \mathrm{~m}$ \\
\hline 17 & $1.22 \mathrm{~m}$ & $1.14 \mathrm{~m}$ & $1.15 \mathrm{~m}$ & $1.63 \mathrm{~m}$ \\
\hline 18 & $0.71 \mathrm{~s}$ & $0.70 \mathrm{~s}$ & $0.75 \mathrm{~s}$ & $0.73 \mathrm{~s}$ \\
\hline 19 & $1.01 \mathrm{~s}$ & $1.00 \mathrm{~s}$ & $1.23 \mathrm{~s}$ & $1.01 \mathrm{~s}$ \\
\hline 20 & $2.07 \mathrm{~m}$ & $1.43 \mathrm{~m}$ & $2.00 \mathrm{~m}$ & $2.53 \mathrm{dq}(8.5,7.0)$ \\
\hline 21 & $1.01 \mathrm{~d}(6.6)$ & $0.95 d(6.5)$ & $1.00 \mathrm{~d}(6.6)$ & $1.03 \mathrm{~d}(7.0)$ \\
\hline 22 & $5.20 \mathrm{dd}(15.3,7.5)$ & $1.42 \mathrm{~m}$ & $5.19 \mathrm{dd}(15.3,7.8)$ & \\
\hline 23 & $5.27 \mathrm{dt}(15.3,8.4)$ & $0.95 \mathrm{~m}$ & $5.27 \mathrm{dt}(15.3,8.4)$ & $2.36 \mathrm{~m}, 2.45 \mathrm{~m}$ \\
\hline 24 & $1.85 \mathrm{~m}$ & & $1.86 \mathrm{~m}$ & $1.43 \mathrm{~m}$ \\
\hline 25 & $1.56 \mathrm{~m}$ & $2.17 \mathrm{~m}$ & $1.28 \mathrm{~m}$ & $1.52 \mathrm{~m}$ \\
\hline 26 & $0.86 \mathrm{~d}(6.6)$ & $1.03(7.0)$ & $0.85 d(6.6)$ & $0.90 \mathrm{~d}(6.9)$ \\
\hline 27 & $0.87 \mathrm{~d}(6.6)$ & $1.03(7.0)$ & $0.86 \mathrm{~d}(6.6)$ & $0.90 \mathrm{~d}(6.9)$ \\
\hline 28 & & $4.66 \mathrm{~s}, 4.72 \mathrm{~s}$ & & \\
\hline
\end{tabular}

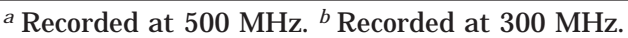

Table 2. ${ }^{13} \mathrm{C}$ NMR Data $(\delta)$ for Metabolites $\mathbf{1 - 4}$ in $\mathrm{CDCl}_{3}$

\begin{tabular}{rrrrr}
\hline & \multicolumn{1}{c}{$\mathbf{1}^{\mathrm{b}}$} & \multicolumn{1}{c}{$\mathbf{2}^{\mathrm{a}}$} & \multicolumn{1}{c}{$\mathbf{3}^{\mathrm{b}}$} & \multicolumn{1}{c}{$\mathbf{4}^{\mathrm{a}}$} \\
\hline 1 & 158.7 & 158.7 & 156.1 & 158.4 \\
2 & 127.4 & 127.3 & 127.5 & 127.4 \\
3 & 200.4 & 202.4 & 186.5 & 200.2 \\
4 & 41.1 & 41.0 & 123.8 & 41.0 \\
5 & 44.4 & 44.3 & 169.5 & 44.2 \\
6 & 28.7 & 28.2 & 33.0 & 27.6 \\
7 & 31.4 & 30.9 & 33.7 & 31.2 \\
8 & 35.7 & 35.7 & 35.6 & 35.6 \\
9 & 50.1 & 49.9 & 52.5 & 49.9 \\
10 & 39.1 & 39.5 & 43.7 & 38.9 \\
11 & 21.3 & 21.2 & 22.9 & 21.2 \\
12 & 39.7 & 39.8 & 39.6 & 39.6 \\
13 & 42.7 & 42.7 & 42.6 & 42.9 \\
14 & 56.5 & 56.3 & 55.6 & 55.7 \\
15 & 24.2 & 24.1 & 24.4 & 24.3 \\
16 & 27.7 & 27.1 & 28.6 & 27.5 \\
17 & 56.0 & 56.0 & 55.9 & 52.1 \\
18 & 12.4 & 12.2 & 12.3 & 12.4 \\
19 & 13.0 & 13.0 & 18.8 & 13.0 \\
20 & 40.2 & 35.7 & 40.1 & 49.4 \\
21 & 20.9 & 18.6 & 20.8 & 16.5 \\
22 & 138.0 & 34.6 & 137.8 & 214.9 \\
23 & 126.5 & 31.3 & 126.6 & 39.7 \\
24 & 42.0 & 156.6 & 42.0 & 32.4 \\
25 & 28.6 & 31.3 & 28.6 & 27.7 \\
26 & 22.4 & 21.8 & 22.3 & 22.4 \\
27 & 22.3 & 22.0 & 22.4 & 22.4 \\
28 & & 106.0 & & \\
\hline
\end{tabular}

a Recorded at $125 \mathrm{MHz}$ (assigned by DEPT, COSY, HSQC, and HMBC experiments). ${ }^{b}$ Recorded at $75 \mathrm{MHz}$ (assigned by DEPT, COSY, HSQC, and HMBC experiments).

signals due to the side chain. The stereochemistry of the side chain was determined by comparison of ${ }^{13} \mathrm{C}$ NMR data with those of stoloniferone $\mathrm{G}^{11}$ and confirmed by NOESY correlations between $\mathrm{H}_{3}-21$ and $\mathrm{H}-12 \beta, \mathrm{H}_{3}-18$ and $\mathrm{H}-20, \mathrm{H}_{3}-$ 18 and $\mathrm{H}-11 \beta$, and $\mathrm{H}_{3}-18$ and $\mathrm{H}-8$.

Compound 3 had a molecular formula of $\mathrm{C}_{27} \mathrm{H}_{40} \mathrm{O}$ as determined by HREIMS. The ${ }^{1} \mathrm{H}$ and ${ }^{13} \mathrm{C}$ NMR spectral data (Tables 1 and 2 ) resembled those of $\mathbf{1}$ except the double bond at C-4. The presence of an $\alpha, \beta-\alpha^{\prime}, \beta^{\prime}$-unsaturated carbonyl group was straightforward from NMR signals at $\delta_{\mathrm{H}} 6.23 / \delta_{\mathrm{C}} 127.5,7.06 / 156.1,6.07 / 123.8,169.5$ (qC), and $186.5(\mathrm{qC})$, an IR absorption at $1676 \mathrm{~cm}^{-1}$, and a UV maximum at $245 \mathrm{~nm}$. HMBC correlations from $\mathrm{H}-1$ to $\mathrm{C}-3 /$ $\mathrm{C}-5$, from $\mathrm{H}-2$ to $\mathrm{C}-4 / \mathrm{C}-10$, and from $\mathrm{H}-4$ to $\mathrm{C}-2 / \mathrm{C}-10$ confirmed the $\alpha, \beta$ - $\alpha^{\prime}, \beta^{\prime}$-unsaturated carbonyl group at ring A. Comparisons of ${ }^{13} \mathrm{C}$ NMR chemical shift values of $\mathbf{3}$ with those of cholesta-1,4-dien-3-ones reported from a soft coral Minabea sp. ${ }^{12}$ disclosed the expected all-trans stereochemistry at the ring junctures of 3. Stereochemistry at C-20 was determined by comparison of ${ }^{13} \mathrm{C}$ NMR data with those of $\mathbf{1}$ and confirmed by NOESY correlation between $\mathrm{H}_{3}-21$ and $\mathrm{H}-12 \beta$. Thus, 3 is a methyl 3-oxocholesta-1,4,22-triene.

Compound 4 had a molecular formula of $\mathrm{C}_{27} \mathrm{H}_{42} \mathrm{O}_{2}$ as determined by HREIMS. The ${ }^{1 \mathrm{H}}$ and ${ }^{13} \mathrm{C}$ NMR spectral data (Tables 1 and 2) were identical with those of cholest1-ene-3,22-dione isolated from the octocoral Alcyonium gracillimum. ${ }^{9}$ However, according to our detailed analysis of the 2D NMR spectra of 4, the ${ }^{1} \mathrm{H}$ and ${ }^{13} \mathrm{C}$ NMR chemical shifts at C-23 and C-24 should be exchanged.

The methylene chloride extract $(37.1 \mathrm{~g})$ of $\mathrm{L}$. cervicorni was chromatographed on a silica gel column using n-hexane- $\mathrm{CH}_{2} \mathrm{Cl}_{2}$ (1:3) as eluent to give compound 5 as colorless crystals (170 mg), which was identified by comparison of physical and spectral data with those of Iemnalol. ${ }^{3}$ The ${ }^{1} \mathrm{H}$ and ${ }^{13} \mathrm{C}$ NMR chemical shifts, which were not completely assigned previously, ${ }^{3}$ were assigned by 1D and 2D NMR (COSY, NOESY, HSQC, HMBC, and 2D INADEQUATE ) methods.

Compound 6 was analyzed for $\mathrm{C}_{15} \mathrm{H}_{24} \mathrm{O}$ by HRFABMS and NMR spectral data. The presence of a secondary alcohol was indicated by IR $\left(3572 \mathrm{~cm}^{-1}\right),{ }^{1} \mathrm{H}$ NMR $(\delta 4.20$ $\mathrm{dt})$, and ${ }^{13} \mathrm{C}$ NMR $(\delta 68.1 \mathrm{CH})$. The presence of an exo-methylene functionality was indicated by ${ }^{1} \mathrm{H}$ NMR $(\delta 4.66 \mathrm{~s}, 4.72 \mathrm{~s})$ and ${ }^{13} \mathrm{C}$ NMR $\left(\delta 107.2 \mathrm{CH}_{2}, 147.8 \mathrm{qC}\right)$. 


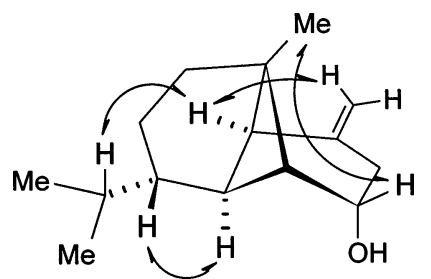

Figure 1. Key NOESY correlations of $\mathbf{6}$.

The ${ }^{13} \mathrm{C}$ NMR also showed signals of three methyl carbons ( $\delta 19.7,20.1,21.6)$, three $\mathrm{sp}^{3}$ methylene carbons $(\delta 36.4$, $24.2,36.8)$, five $\mathrm{sp}^{3}$ methine carbons ( $\delta 48.5,55.6,37.4,44.0$, $32.5)$, and one $\mathrm{sp}^{3}$ quaternary carbon $(\delta 43.0)$. The ${ }^{1} \mathrm{H}$ NMR spectrum of $\mathbf{6}$ showed signals due to a tertiary methyl at $\delta$ $0.68(3 \mathrm{H}, \mathrm{s})$ and an isopropyl group at $\delta 0.89(6 \mathrm{H}, \mathrm{d}, \mathrm{J}=$ $6.6 \mathrm{~Hz})$ and $1.55(1 \mathrm{H}, \mathrm{m})$ in addition to the signals at $\delta$ $2.82(1 \mathrm{H}, \mathrm{dd}, \mathrm{J}=16,8 \mathrm{~Hz}), 2.57(1 \mathrm{H}, \mathrm{d}, \mathrm{J}=5.4 \mathrm{~Hz}), 2.38$ $(1 \mathrm{H}, \mathrm{ddt}, \mathrm{J}=16,8,3 \mathrm{~Hz})$, and $2.24(1 \mathrm{H}, \mathrm{s})$. These NMR features were analogous to those of compound $\mathbf{5}$ with the exception that the resonances for the hydroxymethine at C-4 ( $\left.\delta_{\mathrm{H}} 4.42 \mathrm{~d} ; \delta_{\mathrm{C}} 66.5 \mathrm{CH}\right)$ were replaced by the hydroxymethine at C-5 $\left(\delta_{\mathrm{H}} 4.20 \mathrm{dt} ; \delta_{\mathrm{C}} 68.1 \mathrm{CH}\right)$. Cross-peaks in the ${ }^{1} \mathrm{H}-{ }^{1} \mathrm{H}$ COSY spectrum of $\mathbf{6}$ showed couplings between the hydroxymethine proton at $\delta 4.20(\mathrm{~m}, \mathrm{H}-5)$ and the methine proton at $\delta 1.73(\mathrm{~m}, \mathrm{H}-6)$. HMBC correlations of 6 from $\mathrm{H}-5$ to $\mathrm{C}-3, \mathrm{C}-6$, and $\mathrm{C}-7$ and from $\mathrm{H}-7$ to $\mathrm{C}-1$, C-2, C-3, C-5, C-6, and C-13 comfirmed the location of a secondary hydroxyl at C-5 in 6 instead of C-4 in $\mathbf{5}$. The relative stereochemistry of $\mathbf{6}$ was established by NOESY experiment (Figure 1). NOESY correlations from $\mathrm{H}-5$ to $\mathrm{H}_{3^{-}}$ 11 and $\mathrm{H}-6$ showed that these protons occurred on the same side of the molecule. NOESY correlations from $\mathrm{H}-2$ to $\mathrm{H}-13$ showed that these protons occurred on the other side of the molecule. In the ${ }^{1} \mathrm{H}$ NMR data of $\mathbf{6}$, a large long-range coupling $(\mathrm{J}=5.4 \mathrm{~Hz}$ ) observed between $\mathrm{H}-2(\delta 2.57 \mathrm{~d}$ ) and $\mathrm{H}-6$ indicated the presence of a bridged cyclobutane system. In addition, no coupling was observed between $\mathrm{H}-7$ ( $\delta 2.24$ s) and the adjacent protons $(\mathrm{H}-2, \mathrm{H}-6$, and $\mathrm{H}-8)$, suggesting a dihedral angle of approximately $90^{\circ}$ between these protons. $^{3}$

Compound 7 has the molecular formula $\mathrm{C}_{15} \mathrm{H}_{24} \mathrm{O}$, as determined by HRFABMS and NMR spectral data. The NMR spectra resembled those of $\mathbf{6}$. However, a methylbearing Z-trisubstituted ol efin $\left(\delta_{\mathrm{H}} 1.74 \mathrm{br} \mathrm{s}, 5.42 \mathrm{br} \mathrm{s} ; \delta_{\mathrm{C}}\right.$ $\left.23.0 \mathrm{CH}_{3}, 119.9 \mathrm{CH}, 147.6 \mathrm{qC}\right)$ in 7 replaced the exomethylene in 6. COSY cross-peaks from $\mathrm{H}-4$ to $\mathrm{H}-12$ and $\mathrm{H}-5$ as well as $\mathrm{HMBC}$ correlations between $\mathrm{H}-12$ and $\mathrm{C}-3$, $\mathrm{C}-4$, and $\mathrm{C}-2$ comfirmed the position of the methyl-bearing Z-trisubstituted olefin. In the NOESY experiment, NOES from $\mathrm{H}-5$ to $\mathrm{H}_{3}-11$ and $\mathrm{H}-6$ showed that these protons occurred on the same side of the molecule. NOESY correlations from $\mathrm{H}-2$ to $\mathrm{H}-13$ showed that these protons occurred on the other side of the molecule. Significant differences of ${ }^{13} \mathrm{C}$ NMR chemical shifts (C-2, C-4, C-6, and C-9) from those of the $\beta$-isopropyl stereoisomer ${ }^{13}$ as well as NOESY correlation between $\mathrm{H}-2$ and $\mathrm{H}-13$ of 7 confirmed the $\alpha$-configuration of the isopropyl group.

The molecular formula $\mathrm{C}_{15} \mathrm{H}_{22} \mathrm{O}$ of compound 8 was revealed by HRFABMS and NMR spectral data. The NMR features of compound $\mathbf{8}$ were analogous to those of $\mathbf{7}$ with the exception that the resonance for the 5-hydroxyl methine was replaced by a ketone $\left(\delta_{C}\right.$ 203.3). HMBC correlations between $\mathrm{H}-12$ and $\mathrm{C}-2, \mathrm{C}-3$, and $\mathrm{C}-4 ; \mathrm{H}-6$ and $\mathrm{C}-5$ and $\mathrm{C}-8$; and $\mathrm{H}-7$ and $\mathrm{C}-2, \mathrm{C}-3, \mathrm{C}-5, \mathrm{C}-6, \mathrm{C}-9$, and $\mathrm{C}-13$ confirmed the ketone at $\mathrm{C}-5$. The ${ }^{13} \mathrm{C}$ NMR data of $\mathbf{8}$ were identical with those of oxo- $\alpha$-ylangene, ${ }^{14}$ which was assigned as a $\beta$-isopropyl stereoisomer of $\mathbf{8}$. However, NOESY correlation
Table 3. ${ }^{1} \mathrm{H}$ NMR Data $(\delta)$ for Metabolites 5-8 in $\mathrm{CDCl}_{3}$

\begin{tabular}{|c|c|c|c|c|}
\hline & $5^{a}$ & $6^{b}$ & $7^{b}$ & $8^{b}$ \\
\hline 2 & $2.61 \mathrm{~d}(6.0)$ & $2.57 \mathrm{~d}(5.4)$ & $2.09 \mathrm{~d}(5.4)$ & $2.47 \mathrm{~d}(6.6)$ \\
\hline 4 & $4.42 \mathrm{~d}(7.5)$ & $\begin{array}{l}2.38 \mathrm{ddt}(16.0, \\
8.0,3.0) \\
2.82 \mathrm{dd}(8.0,16.0)\end{array}$ & 5.42 br s & $5.80 \mathrm{br} \mathrm{s}$ \\
\hline 5 & $\begin{array}{c}2.23 \text { ddd }(2.0, \\
8.0,14.0) \\
1.85 \text { ddd }(1.5 \\
4.0,14.0)\end{array}$ & $4.20 \mathrm{dt}(8.0,3.0)$ & 4.27 br s & \\
\hline 6 & $1.65 \mathrm{~m}$ & $1.73 \mathrm{~m}$ & $1.77 \mathrm{~m}$ & $2.27 \mathrm{~d}(6.6)$ \\
\hline 7 & $2.23 \mathrm{~s}$ & $2.24 \mathrm{~s}$ & $1.85 \mathrm{~s}$ & $2.66 \mathrm{~s}$ \\
\hline 8 & $1.55 \mathrm{~m}$ & $1.62 \mathrm{~m}$ & $1.59 \mathrm{~m}$ & $1.69 \mathrm{~m}$ \\
\hline 9 & $1.64 \mathrm{~m}$ & $1.68 \mathrm{~m}$ & $1.68 \mathrm{~m}$ & $1.84 \mathrm{~m}$ \\
\hline 10 & $1.67 \mathrm{~m}$ & $1.69 \mathrm{~m}$ & $1.73 \mathrm{~m}$ & $1.88 \mathrm{~m}$ \\
\hline 11 & $0.63 \mathrm{~s}$ & $0.68 \mathrm{~s}$ & $0.82 \mathrm{~s}$ & $0.97 \mathrm{~s}$ \\
\hline 12 & $\begin{array}{l}4.86 \mathrm{~s} \\
5.04 \mathrm{~s}\end{array}$ & $\begin{array}{l}4.66 \mathrm{~s} \\
4.72 \mathrm{~s}\end{array}$ & $1.74 \mathrm{br} \mathrm{s}$ & $2.02 \mathrm{br} \mathrm{s}$ \\
\hline 13 & $1.51 \mathrm{~m}$ & $1.55 \mathrm{~m}$ & $1.63 \mathrm{~m}$ & $1.66 \mathrm{~m}$ \\
\hline 14 & $0.87 \mathrm{~d}(7.0)$ & $0.89 \mathrm{~d}(6.6)$ & $0.88 d(6.6)$ & $0.85 d(6.6)$ \\
\hline 15 & $0.87 \mathrm{~d}(7.0)$ & $0.89 \mathrm{~d}(6.6)$ & $0.89 \mathrm{~d}(6.6)$ & $0.89 \mathrm{~d}(6.6)$ \\
\hline
\end{tabular}

a Recorded at $500 \mathrm{MHz}$. ${ }^{\mathrm{b}}$ Recorded at $300 \mathrm{MHz}$.

Table 4. ${ }^{13} \mathrm{C}$ NMR Data $(\delta)$ for Metabolites 5-8 in $\mathrm{CDCl}_{3}$

\begin{tabular}{rrrrr}
\hline & \multicolumn{1}{c}{$\mathbf{5}^{\mathrm{a}}$} & \multicolumn{1}{c}{$\mathbf{6}^{\mathrm{b}}$} & \multicolumn{1}{c}{$\mathbf{7}^{\mathrm{b}}$} & \multicolumn{1}{c}{$\mathbf{8}^{\mathrm{b}}$} \\
\hline 1 & 42.3 & 43.0 & 48.8 & 56.9 \\
2 & 47.2 & 48.5 & 44.7 & 46.7 \\
3 & 154.8 & 147.8 & 147.6 & 169.6 \\
4 & 66.5 & 36.4 & 119.9 & 122.3 \\
5 & 34.0 & 68.1 & 70.6 & 203.3 \\
6 & 47.6 & 55.6 & 54.5 & 64.3 \\
7 & 42.0 & 37.4 & 42.0 & 56.4 \\
8 & 44.3 & 44.0 & 44.9 & 44.9 \\
9 & 21.4 & 24.2 & 22.7 & 22.1 \\
10 & 36.5 & 36.8 & 36.9 & 36.7 \\
11 & 20.2 & 19.7 & 18.9 & 20.4 \\
12 & 111.4 & 107.2 & 23.0 & 24.0 \\
13 & 32.3 & 32.5 & 32.5 & 32.0 \\
14 & 20.0 & 21.6 & 19.9 & 19.7 \\
15 & 19.4 & 20.1 & 19.4 & 19.5 \\
\hline
\end{tabular}

a Recorded at $125 \mathrm{MHz}$ (assigned by DEPT, 2D INADEQUATE, COSY, HSQC, and HMBC experiments). ${ }^{b}$ Recorded at $75 \mathrm{MHz}$ (assigned by DEPT, COSY, HSQC, and HMBC experiments).

Table 5. Cytotoxicity of Compounds 1-8

\begin{tabular}{lcc}
\hline & \multicolumn{2}{c}{ cell lines } \\
\cline { 2 - 3 } compound & $9 \mu \mathrm{M})$ \\
\cline { 2 - 3 } $\mathbf{1}$ & $\mathrm{P}-388$ & $\mathrm{HT}-29$ \\
$\mathbf{2}$ & $>100$ & $>100$ \\
$\mathbf{3}$ & 100 & $>100$ \\
$\mathbf{4}$ & 8.93 & $>100$ \\
$\mathbf{5}$ & 16.3 & 9.03 \\
$\mathbf{6}$ & $>50$ & 10.5 \\
$\mathbf{7}$ & $>50$ & $>50$ \\
$\mathbf{8}$ & $>50$ & $>50$ \\
mithramycin & 0.15 & $>50$ \\
& & 0.21 \\
\hline
\end{tabular}

a Mithramicin was used as positive control.

between $\mathrm{H}-2$ and $\mathrm{H}-13$ of $\mathbf{8}$ indicated the $\alpha$-configuration of the isopropyl group. HMBC data led to a revision in the ${ }^{13} \mathrm{C}$ NMR assignments of C-8, C-9, C-10, C-11, and C-12 of oxo- $\alpha$-ylangene assigned by U chio. ${ }^{14,15}$

Cytotoxicity of the isolates is shown in Table 5. Compounds 1, 4, and 5 exhibited cytotoxicity against P-388 with $\mathrm{ED}_{50}$ values of $9.45,8.93$, and $16.3 \mu \mathrm{M}$, respectively. Compounds $\mathbf{4}$ and $\mathbf{5}$ exhibited cytotoxicity against HT-29 with $\mathrm{ED}_{50}$ values of 9.03 and $10.5 \mu \mathrm{M}$, respectively.

\section{Experimental Section}

General Experimental Procedures. Melting points were determined using a Yanagimoto micromelting point apparatus 
and are reported uncorrected. Optical rotations were determined on a J ASCO DIP-181 polarimeter. UV spectra were obtained on a Shimadzu UV-160A spectrophotometer, and IR spectra were recorded on a Hitachi 26-30 spectrophotometer. The NMR spectra were recorded on a Varian Anova 500 or a Bruker Avance 300 spectrometer. The chemical shifts were given in $\delta$ (ppm) and coupling constants in $\mathrm{Hz}$. EIMS spectra were obtained with a J EOL J MS-SX/SX 102A mass spectrometer at $70 \mathrm{eV}$. Si gel 60 (Merck, 230-400 mesh) was used for column chromatography; precoated Si gel plates (Merck, Kieselgel $60 \mathrm{~F}_{254}, 0.25 \mathrm{~mm}$ ) were used for TLC analysis.

Animal Material. The soft coral D. gigantea was collected at Green I sland, off Tai wan, in September 2001, at a depth of 3-4 $\mathrm{m}$ and was stored for 4 weeks in a freezer until extraction. A voucher specimen, NSUGN-048, was deposited in the Department of Marine Resources, National Sun Yat-sen University, Taiwan.

The soft coral L. cervicorni was collected at Green Island, off Taiwan, in December 2000, at a depth of 3-4 m and was stored for 1 week in a freezer until extraction. A voucher specimen, NSUGN-040, was deposited in the Department of Marine Resources, National Sun Yat-sen University, Taiwan.

Extraction and I solation. The soft coral D. gigantea was freeze-dried to give $1.88 \mathrm{~kg}$ of solid, which was extracted with $\mathrm{CH}_{2} \mathrm{Cl}_{2}(4.0 \mathrm{~L} \times 3)$. After removal of solvent in vacuo, the residue (14.2 g) was chromatographed over Si gel 60 using n-hexane and n-hexane-EtOAc mixtures of increasing polarity. Elution by n-hexane-EtOAc (90:10) afforded fractions containing compounds $\mathbf{1}$ and $\mathbf{2}$. Elution by n-hexane-EtOAc (83:17) afforded fractions containing compounds $\mathbf{3}$ and $\mathbf{4}$ Compounds 1-4 were further purified by RP-18 HPLC column by eluting with $\mathrm{MeOH}-\mathrm{H}_{2} \mathrm{O}$ (93:7).

The soft coral $\mathrm{L}$. cervicorni was freeze-dried to give $0.42 \mathrm{~kg}$ of solid, which was extracted with $\mathrm{CH}_{2} \mathrm{Cl}_{2}(3.0 \mathrm{~L} \times 3)$. After removal of solvent in vacuo, the residue $(37.1 \mathrm{~g})$ was chromatographed over Si gel 60 using n-hexane and n-hexane$\mathrm{CH}_{2} \mathrm{Cl}_{2}$ mixtures of increasing polarity. Elution by $n$-hexane$\mathrm{CH}_{2} \mathrm{Cl}_{2}$ (1:3) afforded fractions containing compound 7. Elution by $\mathrm{CH}_{2} \mathrm{Cl}_{2}$ afforded fractions containing compounds 7 and 8 . Elution by $\mathrm{CH}_{2} \mathrm{Cl}_{2}-\mathrm{EtOAC}$ (1:1) afforded fractions containing compound 6. Compound 7 was further purified by $\mathrm{Si}$ gel column chromatography, by eluting with n-hexane- $\mathrm{CH}_{2} \mathrm{Cl}_{2}$ (49:1). Compounds 7 and 8 were further purified by Si gel column chromatography by eluting with n-hexane-acetone (99:1). Compound 6 was further purified by Si gel column chromatography, by eluting with n-hexane-EtOAc (47:3).

Dendronesterone A (1): white solid; $[\alpha]^{25} \mathrm{D}+16^{\circ}$ (c 0.3 , $\left.\mathrm{CHCl}_{3}\right)$; UV (MeOH) $\lambda_{\max }(\log \epsilon) 226$ (3.60) nm; IR (KBr) $v_{\max }$ $1680 \mathrm{~cm}^{-1}$; ${ }^{1} \mathrm{H}$ NMR, see Table $1 ;{ }^{13} \mathrm{C}$ NMR, see Table 2; EIMS $\mathrm{m} / \mathrm{z} 382$ [M] $^{+}$(12), 367 (5), 298 (36), 107 (100); HREIMS, m/z $[\mathrm{M}]^{+} 382.3216$ (calcd for $\mathrm{C}_{27} \mathrm{H}_{42} \mathrm{O}, 382.3225$ ).

Dendronesterone B (2): white solid; $[\alpha]^{25} \mathrm{D}+18^{\circ}$ (c 0.1, $\mathrm{CHCl}_{3}$ ); UV (MeOH) $\lambda_{\max }(\log \epsilon) 222$ (3.56) nm; IR (KBr) $v_{\max }$ $1690 \mathrm{~cm}^{-1}$; ${ }^{1} \mathrm{H}$ NMR, see Table $1 ;{ }^{13} \mathrm{C}$ NMR, seeTable 2; EIMS $\mathrm{m} / \mathrm{z} 396 \mathrm{CM}^{+}$(6), 382 (16), 312 (39), 269 (43), 122 (100); HREIMS, m/z [M] 396.3392 (calcd for $\mathrm{C}_{28} \mathrm{H}_{44} \mathrm{O}, 396.3381$ ).

Dendronesterone C (3): white solid; $[\alpha]^{25} \mathrm{D}+26^{\circ}$ (c 0.6 , $\left.\mathrm{CHCl}_{3}\right) ; \mathrm{UV}(\mathrm{MeOH}) \lambda_{\max }(\log \epsilon) 245$ (4.10) nm; IR (KBr) $v_{\max }$ $1676 \mathrm{~cm}^{-1} ;{ }^{1} \mathrm{H} N M R$, see Table $1 ;{ }^{13} \mathrm{C}$ NMR, see Table 2; EIMS $\mathrm{m} / \mathrm{z} 380$ [M] $^{+}$(8), 365 (2), 270 (20), 122 (100); HREIMS, m/z $[\mathrm{M}]^{+} 380.3066$ (calcd for $\mathrm{C}_{27} \mathrm{H}_{40} \mathrm{O}, 380.3069$ ).

Lemnalol (5): col orless needles; $\mathrm{mp} 47-48^{\circ} \mathrm{C} ;[\alpha]^{25} \mathrm{D}-7.89^{\circ}$ (c 0.60, $\mathrm{CHCl}_{3}$ ); UV (MeOH) $\lambda_{\max }(\log \epsilon) 214(3.50) \mathrm{nm}$; IR (KBr) $v_{\max } 3558,1634 \mathrm{~cm}^{-1} ;{ }^{1} \mathrm{H}$ NMR, see Table $3 ;{ }^{13} \mathrm{C}$ NMR, see

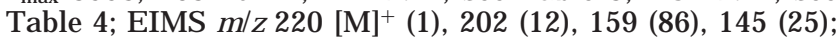
HRFABMS, $\mathrm{m} / \mathrm{z}[\mathrm{M}+\mathrm{H}]^{+} 221.1904$ (calcd for $\mathrm{C}_{15} \mathrm{H}_{25} \mathrm{O}$, 221.1906).

Isolemnalol (6): oil; $[\alpha]^{25} \mathrm{D}+3.33^{\circ}$ (c $0.66, \mathrm{CHCl}_{3}$ ); UV $(\mathrm{MeOH}) \lambda_{\max }(\log \epsilon) 212(3.56) \mathrm{nm}$; IR $(\mathrm{KBr}) v_{\max } 3572,1630$ $\mathrm{cm}^{-1}$; ${ }^{1} \mathrm{H}$ NMR, see Table $3 ;{ }^{13} \mathrm{C}$ NMR, see Table 4; EIMS m/z $220[\mathrm{M}]^{+}$(3), 202 (6), 187 (9), 159 (3), 136 (41), 105 (63); HRFABMS, $\mathrm{m} / \mathrm{z}[\mathrm{M}+\mathrm{H}]^{+} 221.1909$ (calcd for $\mathrm{C}_{15} \mathrm{H}_{25} \mathrm{O}$, 221.1906).

Cervicol (7): oil; $[\alpha]^{25} \mathrm{D}-70.8^{\circ}$ (c 0.80, $\left.\mathrm{CHCl}_{3}\right)$; UV (MeOH) $\lambda_{\max }(\log \epsilon) 212(3.88) \mathrm{nm}$; IR (KBr) $\nu_{\max } 3582,1632 \mathrm{~cm}^{-1} ;{ }^{1} \mathrm{H}$ NMR, see Table 3; ${ }^{13} \mathrm{C}$ NMR, see Table 4; EIMS m/z 202 [M - $\left.\mathrm{H}_{2} \mathrm{O}\right]^{+}$(7), 154 (14), 137 (16), 119 (40); HRFABMS, m/z $[\mathrm{M}+\mathrm{H}]^{+} 221.1899$ (calcd for $\mathrm{C}_{15} \mathrm{H}_{25} \mathrm{O}, 221.1906$ ).

4-Oxo- $\alpha$-ylangene (8): oil; $[\alpha]^{25} \mathrm{D}+8.7^{\circ}$ (c $0.62, \mathrm{CHCl}_{3}$ ); UV $(\mathrm{MeOH}) \lambda_{\max }(\log \epsilon) 225(4.39) \mathrm{nm}$; IR $(\mathrm{KBr}) v_{\max } 1710,1638$ $\mathrm{cm}^{-1} ;{ }^{1} \mathrm{H}$ NMR, see Table $3 ;{ }^{13} \mathrm{C}$ NMR, see Table 4; EIMS m/z $218\left[\mathrm{M}^{+} \text {(1), } 203 \text { (3), } 152 \text { (32); HRFABMS, m/z [M + H] }\right]^{+}$ 219.1746 (calcd for $\mathrm{C}_{15} \mathrm{H}_{23} \mathrm{O}, 219.1750$ ).

Cytotoxicity Testing. P-388 cells were supplied by J . M. Pezzuto, Department of Medicinal Chemistry and Pharmacognosy, University of Illinois at Chicago; A549 and HT-29 were purchased from the American Type Culture Collection. Cytotoxicity assays were carried out according to the procedure described previously. ${ }^{8}$

Acknowledgment. We thank J . M. Pezzuto, Department of Medicinal Chemistry and Molecular Pharmacology, Purdue University, for providing the P-388 cell lines. This work was supported by grants from the National Science Council of Taiwan awarded to C.-Y.D.

Supporting Information Available: ${ }^{1} \mathrm{H}-{ }^{1} \mathrm{H}$ COSY and HMBC correlations of $\mathbf{1}$ and ${ }^{13} \mathrm{C}-{ }^{13} \mathrm{C}$ homonuclear shift correlation $2 \mathrm{D}$ spectrum (INADEQUATE) of $\mathbf{5}$. This material is available free of charge via the Internet at http://pubs.acs.org.

\section{References and Notes}

(1) J urek, J .; Scheuer, P. J . J . Nat. Prod. 1993, 56, 508-513.

(2) Kikuchi, H.; Manda, T.; Kobayashi, H.; Yamada, Y.; I guchi, K. Chem. Pharm. Bull. 1983, 31, 1086-1088.

(3) Kikuchi, H.; Tsukitani, Y.; Yamada, Y.; Iguchi, K.; Drexler, S. A.; Clardy, J. Tetrahedron Lett. 1982, 23, 1063-1066.

(4) Tomono, Y.; Hirota, H.; Fusetani, N. J . Org. Chem. 1999, 64, 2272 2275.

(5) Tomono, Y.; Hirota, H.; I mahara, Y.; Fusetani, N. J . Nat. Prod. 1999, 62, 1538-1541.

(6) Yoshikawa, K.; Kanekuni, S.; Hnahusa, M.; Arihara, S.; Ohta, Y. J . Nat. Prod. 2000, 63, 670-672

(7) Geran, R. I.; Greenberg, N. H.; MacDonald, M. M.; Schumacher, A. M.; Abbott, B. J . Cancer Chemother. Rep. 1972, 3, 1-91.

(8) Hou, R.-S.; Duh, C.-Y.; Chiang, M. Y.; Lin, C.-N. J . Nat. Prod. 1995, $58,1126-1130$.

(9) Seo, Y.; J ung, J . H.; Rho, J . R.; Shin, J .; Shon, J . Tetrahedron 1995, 51, 2497-2506.

(10) Gauvin, A.; Smadja, J .; Aknin, M.; Faure, R.; Gaydou, E.-M. Can. J Chem. 2000, 78, 986-992.

(11) Duh, C.-Y.; El-Gamal, A. A. H.; Chu, C.-J .; Wang, S.-K.; Dai, C.-F.J J Nat. Prod. 2002, 65, 1535-1539.

(12) Ksebati, M.; Schmitz, F. J . J . Org. Chem. 1988, 53, 3926-3929.

(13) Daniewski, W.; Anczewski, W.; Gumulka, M.; Danikiewic, W.; Jacobsson, U. Norin, T. Phytochemistry 1996, 43, 811-814.

(14) Uchio, Y. Tetrahedron 1978, 34, 2893-2899.

(15) Uchio, Y.; Matsuo, A.; Eguchi, S.; Nakayama, M.; Hayashi, S. Tetrahedron Lett. 1977, 1191-1194.

NP030550L 